\title{
A Review of the Potential Benefits of Pentoxifylline in Diabetic and Non- Diabetic Proteinuria
}

\author{
Shirinsadat Badri ${ }^{1}$, Simin Dashti-Khavidaki ${ }^{1,2}$, Mahboob Lessan-Pezeshki ${ }^{2}$, Mohammad Abdollahi ${ }^{3}$ \\ ${ }^{1}$ Department of Clinical Pharmacy, Faculty of Pharmacy, Tehran University of Medical Sciences, Tehran, Iran. \\ ${ }^{2}$ Nephrology Research Center, Tehran University of Medical Sciences, Tehran, Iran. \\ ${ }^{3}$ Faculty of Pharmacy, and Pharmaceutical Sciences Research Center, Tehran University of Medical Sciences, Tehran, Iran.
}

Received, January 30, 2011; Accepted, April 8, 2011; Published, April 9, 2011.

\section{SUMMARY}

Chronic kidney disease (CKD) as a considerable health problem may have proteinuria as the main complication and strong risk factor to reach end-stage renal disease (ESRD). Decreasing proteinuria is the mainstay of therapy in order to delay the progression of CKD. Current therapeutic regimens provide only partial renoprotection, and a substantial number of patients who have proteinuria progress to ESRD. Pentoxifylline (PTF) is known for its potent inhibitory effects against cell proliferation and inflammation which play important roles in CKD progression. Data derived from both human studies and animal models demonstrated that PTF has broadspectrum renoprotective effects and therefore, provide a scientific basis for the use of PTF as an anti-proteinuric agent.

Conclusion of this review is that short-term use of PTF may produce a significant reduction of proteinuria in subjects with diabetic and also non-diabetic kidney diseases but the reports of long-term use of PTF also show that urinary protein excretion exhibits a progressive and sustained reduction in patients treated with PTF. Whether the long-term use of PTF could be a pharmacological alternative for delaying or preventing the development of end stage renal disease, is among the questions that remained to be appropriately answered in large-scale clinical trials.

\section{INTRODUCTION}

Chronic kidney disease (CKD) is a considerable health problem with growing prevalence worldwide as the population ages and the incidence of hypertension and diabetes increases (1). Generally, kidney disease progresses slowly; however, even a small decrease in the rate of kidney function loss results in a marked effect on the time to the development of end-stage renal disease (ESRD) (2). Prevention of renal disease is the most important and effective strategy to decrease the prevalence and incidence of CKD and thus ESRD. Although, a number of diseases that cause CKD are not yet preventable and kidney diseases in most patients are detected at some stages after substantial renal damage (3). The currently available therapeutic interventions for slowing progression of CKD include intensive glycemic control in diabetic patients, strict control of blood pressure, restriction of dietary protein intake, and optimizing reninangiotensin-aldosterone system (RAAS) blockade.
These interventions actively slow but do not halt the progression of CKD in most cases. In fact, all therapies currently available are only partially effective against the renal end points of ESRD (4, $5)$.

Proteinuria denotes a sign of glomerular diseases and represents a marker of injury to the glomerular permeability barrier. Proteinuria, even at a sub-nephrotic range, is a well-known risk factor for cardiovascular mortality and morbidity, and strongly associated with the progression of kidney disease. Urinary protein excretion has been used as a surrogate end point for therapeutic interventions of CKD where decreasing proteinuria would delay the progression of $\mathrm{CKD}$, and cardiovascular morbidity $(6,7)$.

Corresponding Author: Mohammad Abdollahi, Faculty of Pharmacy, and Pharmaceutical Sciences Research Center, Tehran University of Medical Sciences, Iran, Email Address: mohammad@tums.ac.ir 
Although pharmacological inhibition of RAAS has been regarded as the mainstay of therapy for the management of proteinuria, the rate of remission is almost low (8) and side effects are common. Therefore, studies for better drugs are ongoing (9). Because of the pathogenetic complexity of kidney disease, several drugs are usually used together to control kidney disease progression (10-12), but the aim is to achieve the maximal antiproteinuric effect (13).

Pentoxifylline (PTF) is a methylxanthine phosphodiesterase inhibitor which has been in clinical use since the late 1970s and was used primarily to treat patients with peripheral vascular disease $(14,15)$. In addition to its hemorheologic activity, it has been experimentally shown to have potent antiproliferative, anti-inflammatory $(16,17)$, anti-diabetic (18), anti cellular damage $(19,20)$, and antifibrotic effects (21). The hemorheological properties and the potential to improve circulation and some indices of kidney function led to an early interest in the use of PTF as a therapeutic agent in patients with kidney disease (22-24). Data derived from both human studies and animal models provide a strong scientific basis for the use of PTF as an antiproteinuric agent (25-33). The most likely explanation for the antiproteinuric effect of PTF involves its ability to down-regulate the production of proinflammatory cytokines $(34,35)$. Glomerulonephritis is a proinflammatory state (36), and there is evidence suggesting that proinflammatory cytokines may have a pathogenic role in increasing glomerular permeability to proteins (37). Considering the prognostic impact of proteinuria reduction on long-term renal outcome, and taking into account that PTF exerts favorable hemorheological and anti-inflammatory effects result in reducing proteinuria, the use of PTF in the early stage of proteinuric kidney disease is rationale and seems promising.

In the present review all clinical and nonclinical studies on the use of PTF as an antiproteinuric agent have been evaluated and criticized.

\section{METHODS}

Materials for this review were obtained by searching Medline, PubMed, Scopus, Cochrane central register of controlled trials, and Cochrane database systematic reviews. Key words used as search terms were "pentoxifylline", "proteinuria" "urinary protein excretion", "chronic kidney diseases", "kidney disease", and "nephropathy". This search was performed without time limitation. Major well-designed studies which used proteinuria as a main surrogate end point were included.

\section{Non-clinical Studies on the Use of PTF as An Antiproteinuric Agent}

Although PTF primarily was indicated for the treatment of peripheral vascular disease,

\begin{tabular}{|c|c|c|c|c|}
\hline Study & Animal models & $\begin{array}{c}\text { Administration } \\
\text { plan }\end{array}$ & $\begin{array}{l}\text { Study } \\
\text { Period }\end{array}$ & Beneficial effects of PTF \\
\hline $\begin{array}{l}\text { Chen et al } \\
(1999)^{30}\end{array}$ & $\begin{array}{l}\text { Rats with anti-Thyl } \\
\text { nephritis }\end{array}$ & $\begin{array}{l}0.1 \mathrm{~g} / \mathrm{kg} / \mathrm{day}, \mathrm{IJ} \\
\text { infusion }\end{array}$ & 5 days & $\begin{array}{c}\text { PTF attenuated proteinuria and glomerular } \\
\text { sclerosis }\end{array}$ \\
\hline $\begin{array}{l}\text { Segal et al } \\
(2001)^{38}\end{array}$ & $\begin{array}{l}\text { Rats with immunization- } \\
\text { induce SLE-like disease }\end{array}$ & $100 \mu \mathrm{g}$ daily, IP & 6 weeks & $\begin{array}{l}\text { PTF decreased proteinuria and immune } \\
\text { complex deposition }\end{array}$ \\
\hline $\begin{array}{l}\text { Lin et al } \\
(2002)^{16}\end{array}$ & $\begin{array}{l}\text { Rats with remnant } \\
\text { kidney }\end{array}$ & $\begin{array}{l}400 \mathrm{mg} / \mathrm{L} \text { of } \\
\text { drinking water }\end{array}$ & 8 weeks & $\begin{array}{l}\text { PTF attenuated proteinuria, interstitial } \\
\text { inflammation \& renal disease progression }\end{array}$ \\
\hline $\begin{array}{l}\text { Chen et al } \\
(2004){ }^{17}\end{array}$ & $\begin{array}{l}\text { Rats with crescentic } \\
\text { glomerulonephritis }\end{array}$ & $0.1 \mathrm{~g} / \mathrm{kg} /$ day, IV & 28 days & $\begin{array}{l}\text { PTF suppressed 24-h urinary protein } \\
\text { excretion \& progressive renal injury }\end{array}$ \\
\hline $\begin{array}{l}\text { Usta et al } \\
(2004)^{29}\end{array}$ & $\begin{array}{l}\text { Rats with ADR-induced } \\
\text { nephropathy }\end{array}$ & $\begin{array}{c}1 \mathrm{~g} / \mathrm{L} \text { of } \\
\text { drinking water }\end{array}$ & 21 days & $\begin{array}{l}\text { PTF decreased proteinuria, urine nitrite, and } \\
\text { apoptosis in the renal tissue }\end{array}$ \\
\hline $\begin{array}{l}\text { Navarro et al } \\
\quad(2006)^{39}\end{array}$ & $\begin{array}{l}\text { Rats with STZ-induced } \\
\text { diabetic nephropathy }\end{array}$ & $\begin{array}{c}1 \mathrm{~g} / \mathrm{L} \text { of } \\
\text { drinking water }\end{array}$ & 8 weeks & $\begin{array}{c}\text { PTF reduced albuminuria \& urinary cytokine } \\
\text { excretion }\end{array}$ \\
\hline $\begin{array}{l}\text { Han et al } \\
(2010)^{31}\end{array}$ & $\begin{array}{l}\text { Rats with STZ-induced } \\
\text { diabetic nephropathy }\end{array}$ & $\begin{array}{l}40 \mathrm{mg} / \mathrm{kg} \text {, per } \\
\text { oral }\end{array}$ & $\begin{array}{l}4 \text { and } 8 \\
\text { weeks }\end{array}$ & $\begin{array}{c}\text { Administration of PTF for } 4 \text { weeks inhibited } \\
\text { the renal inflammatory reaction, } \& \\
\text { administration for } 8 \text { weeks prevented } \\
\text { proteinuria }\end{array}$ \\
\hline
\end{tabular}


renoprotective and antiproteinuric effects of PTF have been observed in animal studies (Table 1).

In vivo studies have shown beneficial effects of PTF in reduction of proteinuria in different animal models of renal disease, including murine lupus nephritis (38), crescentic glomerulonephritis (17) and an experimental model of adriamycin-induced nephropathy in rats (29). As demonstrated in experimental nephritic rats, one of the possible mechanisms for the renoprotection may be linked to the effect of PTF against the proliferation of glomerular mesangial cells and interstitial fibroblasts (30). A recent work in rats with a remnant kidney demonstrated the significant effects of PTF in modulating inflammation, cell proliferation, and fibrosis. PTF attenuated the progression of renal disease, ameliorated proteinuria, and had a beneficial effect on the renal survival of these rats (16). In addition, in streptozotocin-induced diabetic rats, PTF was effective against the fall in glomerular filtration rate (GFR) and reduced urinary albumin excretion (39).

Recently, the antiproteinuric effect of prolonged administration of PTF was investigated in rats with streptozotocin-induced diabetic nephropathy. The amount of urinary protein was higher in the diabetic rats than that of control group. The amount remained unchanged after 4 weeks and decreased after 8 weeks of PTF treatment. These findings support the hypothesis that prolonged administration enhances the protective effects of PTF (31).

\section{Clinical Use of PTF as an Antiproteinuric Agent in Human Studies}

\section{Use of PTF in Diabetic Kidney Disease}

The incidence of diabetes is rising, with alarming increases in prevalence of its complications mainly diabetic kidney disease. Diabetic nephropathy is a proinflammatory state, and there is evidence suggesting that proinflammatory cytokines may have a pathogenic role in increasing glomerular permeability to albumin. Currently, treatment of diabetic nephropathy has emphasized on better management of hyperglycemia and control of the RAAS (7, 40). Obviously, current therapeutic regimens have not yet provided satisfactory control of diabetic complications; hence, most of new strategies focused on controlling the GFR decline and proteinuria.

To date, a number of clinical trials evaluating PTF in patients with diabetic kidney disease have been conducted (Table 2). Searching PubMed considering this topic revealed that the first clinical experience of antiproteinuric effect of PTF was reported in 1982 by Blagosklonnaia et al. in which some renal function parameters was assessed in 11 diabetic patients who received intravenous PTF 300 mg per day for three weeks. PTF significantly improved GFR and decreased proteinuria in the studied patients (22).

\begin{tabular}{ccccccc}
\hline Table 2. Selected clinical studies of antiproteinuric effect of pentoxifylline in diabetic kidney disease \\
\hline Study & $\begin{array}{c}\text { Patient } \\
\text { No. }\end{array}$ & Subjects & $\begin{array}{c}\text { Treatment } \\
\text { plan }\end{array}$ & Control Group & $\begin{array}{c}\text { Follow } \\
\text { up } \\
\text { Period }\end{array}$ & Outcome \\
\hline $\begin{array}{c}\text { Blagosklonnaia } \\
\text { et al (1982) }{ }^{19}\end{array}$ & 11 & $\begin{array}{c}\text { Diabetic patients } \\
\text { with clinical } \\
\text { signs of diabetic } \\
\text { nephropathy }\end{array}$ & $300 \mathrm{mg}$ daily & - & 3 & $\begin{array}{c}\text { Marked improvement of } \\
\text { renal function: GFR } \\
\text { increased, proteinuria } \\
\text { diminished }\end{array}$ \\
Solerte et al \\
$(1986)^{38}$
\end{tabular}




\begin{tabular}{|c|c|c|c|c|c|c|}
\hline $\begin{array}{l}\text { Guerrero- } \\
\text { Romero et al } \\
(1995)^{23}\end{array}$ & 86 & $\begin{array}{l}\text { Type } 1 \text { and type } \\
2 \text { diabetes with a } \\
\text { wide range of } \\
\text { urinary protein } \\
\text { excretion }\end{array}$ & $\begin{array}{l}1200 \mathrm{mg} \\
\text { daily }\end{array}$ & Placebo & $\begin{array}{c}4 \\
\text { months }\end{array}$ & $\begin{array}{l}\text { Overt proteinuria and } \\
\text { microalbuminuria } \\
\text { significantly decreased } \\
\text { compared to placebo } \\
\text { group }\end{array}$ \\
\hline $\begin{array}{l}\text { Navarro et al } \\
(1999))^{40}\end{array}$ & 24 & $\begin{array}{l}\text { Diabetic patients } \\
\text { with advanced } \\
\text { renal failure }\end{array}$ & $400 \mathrm{mg}$ daily & $\begin{array}{l}\text { Untreated control } \\
\text { group }\end{array}$ & $\begin{array}{c}6 \\
\text { months }\end{array}$ & $\begin{array}{l}\text { Proteinuria significantly } \\
\text { decreased in PTF group } \\
\text { compared to control } \\
\text { group }\end{array}$ \\
\hline $\begin{array}{l}\text { Navarro et al } \\
\quad(2003)^{41}\end{array}$ & 45 & $\begin{array}{l}\text { Patients with } \\
\text { early type } 2 \\
\text { diabetic } \\
\text { nephropathy }\end{array}$ & $\begin{array}{c}1200 \mathrm{mg} \\
\text { daily }\end{array}$ & $\begin{array}{l}\text { Untreated control } \\
\text { group }\end{array}$ & $\begin{array}{c}4 \\
\text { months }\end{array}$ & $\begin{array}{l}\text { PTF combined with } \\
\text { RAAS blockade further } \\
\text { reduced proteinuria and } \\
\text { protect the kidney } \\
\text { compared to control } \\
\text { group }\end{array}$ \\
\hline $\begin{array}{l}\text { Navarro et al } \\
\quad(2005)^{13}\end{array}$ & 61 & $\begin{array}{l}\text { Normotensive } \\
\text { patients with } \\
\text { diabetic } \\
\text { nephropathy and } \\
\text { residual } \\
\text { albuminuria }\end{array}$ & $\begin{array}{c}1200 \mathrm{mg} \\
\text { daily }+ \\
\text { recommended } \\
\text { doses of ARB }\end{array}$ & $\begin{array}{l}\text { Treatment with } \\
\text { recommended } \\
\text { doses of ARB }\end{array}$ & $\begin{array}{c}4 \\
\text { months }\end{array}$ & $\begin{array}{l}\text { Significant additive } \\
\text { antiproteinuric effect } \\
\text { compared to control } \\
\text { group }\end{array}$ \\
\hline $\begin{array}{c}\text { Harmankaya et } \\
\text { al } \\
(2003)^{42}\end{array}$ & 50 & $\begin{array}{c}\text { Type } 2 \text { diabetic } \\
\text { patients }\end{array}$ & $\begin{array}{c}600 \mathrm{mg} \text { daily } \\
+ \\
\text { lisinopril } 10 \\
\text { mg daily }\end{array}$ & $\begin{array}{c}\text { Lisinopril } 10 \mathrm{mg} \\
\text { daily }\end{array}$ & $\begin{array}{c}9 \\
\text { months }\end{array}$ & $\begin{array}{l}\text { Significant additive } \\
\text { antiproteinuric effect } \\
\text { compared to control } \\
\text { group }\end{array}$ \\
\hline $\begin{array}{c}\text { Aminorroaya } \\
\text { et al } \\
(2005)^{43}\end{array}$ & 39 & $\begin{array}{l}\text { Type } 2 \text { diabetic } \\
\text { patients }\end{array}$ & $\begin{array}{l}1200 \mathrm{mg} \\
\text { daily }\end{array}$ & $\begin{array}{c}\text { Captopril } 75 \mathrm{mg} \\
\text { daily }\end{array}$ & $\begin{array}{c}2 \\
\text { months }\end{array}$ & $\begin{array}{l}\text { PTF was as effective as } \\
\text { captopril in reducing } \\
\text { overt proteinuria }\end{array}$ \\
\hline $\begin{array}{l}\text { Rodriguez- } \\
\text { Moran et al } \\
(2005)^{44}\end{array}$ & 130 & $\begin{array}{c}\text { Type } 2 \text { diabetic } \\
\text { patients }\end{array}$ & $\begin{array}{c}1200 \mathrm{mg} \\
\text { daily }\end{array}$ & $\begin{array}{l}\text { Captopril } 75 \mathrm{mg} \\
\text { daily }\end{array}$ & $\begin{array}{c}6 \\
\text { months }\end{array}$ & $\begin{array}{l}\text { PTF was as effective as } \\
\text { captopril in reducing } \\
\text { microalbuminuria }\end{array}$ \\
\hline $\begin{array}{l}\text { Rodriguez- } \\
\text { Moran et al } \\
(2006)^{45}\end{array}$ & 40 & $\begin{array}{l}\text { Type } 2 \text { diabetes } \\
\text { and } \\
\text { microalbuminuria }\end{array}$ & $\begin{array}{l}1200 \mathrm{mg} \\
\text { daily }\end{array}$ & Placebo & $\begin{array}{c}16 \\
\text { weeks }\end{array}$ & $\begin{array}{l}\text { Microalbuminuria } \\
\text { significantly decreased } \\
\text { compared to placebo } \\
\text { group }\end{array}$ \\
\hline $\begin{array}{l}\text { Diskin et al } \\
(2007){ }^{46}\end{array}$ & 7 & $\begin{array}{l}\text { Diabetic men } \\
\text { with primarily } \\
\text { nephrotic-range } \\
\text { proteinuria }\end{array}$ & $\begin{array}{l}\text { PTF dose } \\
\text { adjusted for } \\
\text { creatinine } \\
\text { clearance }+ \\
\text { Maximal } \\
\text { doses of } \\
\text { ACEIs and } \\
\text { ARBs }\end{array}$ & $\begin{array}{l}\text { Treatment with } \\
\text { maximal doses of } \\
\text { ACEIs and ARBs }\end{array}$ & 1 year & $\begin{array}{l}\text { Non-significant trend } \\
\text { toward improvement in } \\
\text { proteinuria compared } \\
\text { with control group }\end{array}$ \\
\hline $\begin{array}{l}\text { Roozbeh et al } \\
\quad(2010)^{47}\end{array}$ & 74 & $\begin{array}{l}\text { Type } 2 \text { diabetic } \\
\text { patients with } \\
\text { overt proteinuria }\end{array}$ & $\begin{array}{l}1200 \mathrm{mg} \\
\text { daily }+ \\
\text { captopril } 75 \\
\text { mg daily }\end{array}$ & $\begin{array}{l}\text { Captopril } 75 \mathrm{mg} \\
\text { daily }\end{array}$ & $\begin{array}{c}6 \\
\text { months }\end{array}$ & $\begin{array}{l}\text { Proteinuria reduction in } \\
\text { PTF group was nearly } \\
\text { three-fold that of } \\
\text { control group }\end{array}$ \\
\hline
\end{tabular}

In the past few years there has been ongoing interest in the use of PTF as an antiproteinuric agent in patients with a variety of renal diseases, mostly diabetic nephropathy. The early randomized controlled clinical trials demonstrating the beneficial effect of oral PTF in the reduction of microproteinuria were first published in 1986 and further investigated in 1987 by Solerte and 
colleagues. According to the results of these two studies, a significant improvement of blood rheology pattern together with a marked reduction of urinary albumin and total protein excretion rates were demonstrated in the diabetic patients treated with PTF $(41,42)$. These studies indicate that PTF may be effective for preventing or delaying the progression of kidney disease and might be useful in the treatment of diabetic microproteinuria.

In one randomized double-blind placebocontrolled study published in 1995, GuerreroRomero et al. assessed the effect of PTF in 86 patients with type 1 and type 2 diabetes with a wide range of urinary protein excretion. Patients randomly allocated to receive either PTF $1200 \mathrm{mg}$ daily or placebo for four months. Both overt proteinuria and microalbuminuria significantly decreased in the patients with both types of diabetes who received PTF compared with control subgroups who received placebo (26). These results confirmed previous findings reporting an antiproteinuric effect of PTF in patients with diabetic nephropathy.

Limited short-term human studies proved PTF add-on efficacy in decreasing proteinuria in patients with diabetes using angiotensin-converting enzyme inhibitors (ACEIs) or angiotensin II receptor blockers (ARBs). In a clinical trial by Navarro et al. in 1999, 24 diabetic patients with advanced renal failure were randomly allocated to receive PTF (400 mg daily) for 6 months or no additional treatment. Monotherapy with PTF markedly decreased proteinuria of diabetic patients. Conversely, proteinuria was not changed in the control group. None of the studied patients received ACEI or ARB (43). Soon after in 2003, Navarro et al. evaluated the additive antiproteinuric effect of PTF in 30 patients with early type 2 diabetic nephropathy who were already receiving treatment with ACEI or ARB. Administration of PTF (1200 $\mathrm{mg}$ daily) for 4 months in these patients further reduced urinary protein excretion compared with data from a control group (44). These findings suggest that PTF may have beneficial effects on tubulointerstitial damage in patients with diabetic kidney disease and provide clinical evidence that PTF combined with RAAS blockade may further reduce proteinuria and protect the kidney.

Navarro et al. further investigated this hypothesis by conducting another study in 2005 in order to assess the additive antiproteinuric effect of oral PTF in type 2 diabetic patients. In this study, 61 patients with diabetic nephropathy and residual albuminuria despite treatment with the appropriate doses of ARB for more than one year, were randomly assigned to receive the addition of 1200 mg of PTF daily or to a control group (13). This hypothesis was also tested in 2003 by Harmankaya et al. in which the combination of PTF $(600 \mathrm{mg}$ daily for 9 months) with ACEI was assessed regarding additional reduction in microalbuminuria in 25 type 2 diabetic patients compared to a placebo group (45). In both of these randomized placebocontrolled studies, the authors concluded that administration of PTF to diabetic patients under long-term treatment with an ACEI or ARB produces a significant additive antiproteinuric effect.

Two other studies published in the same year compared the antiproteinuric effect of PTF with an ACEI, captopril, in type 2 diabetic patients which randomly allocated to receive oral PTF (1200 mg daily) or captopril (25 $\mathrm{mg}$ three times per day) for two (46) or six (47) months. PTF has been demonstrated to be as effective as captopril in reducing overt proteinuria and microalbuminuria in type 2 diabetic patients, suggesting that PTF could be an effective alternative to ACE inhibitors in reducing urinary protein excretion.

Recently, in order to identify the effect of PTF on the urinary protein excretion in patients not treated with RAAS inhibition, a clinical trial was conducted among 40 patients with type 2 diabetes and microalbuminuria. At the end of follow-up, microalbuminuria significantly decreased in the patients who received PTF (1200 mg daily, for 16 weeks), and remained without significant changes in the subjects with placebo. Also, it is demonstrated that PTF significantly reduces the urinary excretion of both low and high molecularweight proteins (48).

Diskin et $a l$, in a small nonrandomized trial examined the impact of PTF on kidney function in patients with advanced CKD currently using RAAS inhibition. This study included 7 diabetic men with primarily nephrotic-range proteinuria and advanced CKD on maximal doses of both an ACE inhibitor and an ARB, and showed that PTF therapy for 1 year produced a non-significant trend toward improvement in proteinuria compared with matched controls. Although no significant difference in rate of decrease in kidney function was identified, the 
PTF group had nearly $50 \%$ less decrease during the one year-long study compared with the control group (49).

Most recently, antiproteinuric efficacy of combining an ACE inhibitor, captopril, and PTF was evaluated in 74 type 2 diabetic patients with overt proteinuria. Patients randomly assigned to two groups (group 1: captopril $25 \mathrm{mg}$ three times a day, group 2: captopril $25 \mathrm{mg}$ and PTF $400 \mathrm{mg}$ each three times per day). The reduction in urinary protein excretion was similar in the two groups until the end of the second month, while at six months, the reduction in group 2 (PTF + captopril) was nearly three-fold that of group 1 (captopril). Authors concluded that combining an angiotensinconverting enzyme inhibitor and PTF can lead to a greater reduction in proteinuria (50).

The clinical evidences that show the efficacy of PTF in the management of microalbuminuria in diabetic patients were reviewed by RodriguezMorán, et al. According to this review, current evidence consistently shows that short-term use of PTF significantly reduces both the overt proteinuria and microalbuminuria in subjects with diabetes suggesting that PTF could be useful for the treatment of diabetic nephropathy (9).

These positive effects were summarized by McCormick and colleagues in a meta-analysis reviewing all randomized controlled trials that involved adult patients with proteinuria secondary to diabetic kidney disease who received oral PTF (7). Based on statistical analysis, the authors concluded that PTF is an efficacious antiproteinuric agent (versus placebo or usual care) with a significant impact only in overt proteinuria (urine protein $>300 \mathrm{mg} / \mathrm{d}$ ), but no significant change in microalbuminuria. Although, the main limitations of their review are that the studies included small numbers of patients, were of short duration, used different doses of PTF and that methods quality was poor.

\section{Use of PTF in Non-Diabetic Kidney Disease}

Parallel to the findings on diabetic nephropathy, clinical trials in patients with non-diabetic renal diseases such as membranous glomerulonephritis

\begin{tabular}{|c|c|c|c|c|c|c|}
\hline Study & $\begin{array}{l}\text { Patient } \\
\text { No. }\end{array}$ & Subjects & $\begin{array}{c}\text { Treatment } \\
\text { plan }\end{array}$ & $\begin{array}{l}\text { Control } \\
\text { Group }\end{array}$ & $\begin{array}{l}\text { Follow up } \\
\text { Period }\end{array}$ & Outcome \\
\hline $\begin{array}{l}\text { Ducloux et al } \\
\quad(2001)^{48}\end{array}$ & 10 & $\begin{array}{l}\text { Biopsy-proved } \\
\text { membranous } \\
\text { nephropathy }\end{array}$ & $1200 \mathrm{mg}$ daily & - & 6 months & Remission of proteinuria \\
\hline $\begin{array}{l}\text { Chen et al } \\
(2006)^{32}\end{array}$ & 17 & $\begin{array}{l}\text { Non-diabetic patients } \\
\text { with primary } \\
\text { glomerular disease } \\
\text { and persistent } \\
\text { proteinuria }\end{array}$ & $800 \mathrm{mg}$ daily & - & 6 months & $\begin{array}{l}\text { Urinary protein excretion } \\
\text { reduced significantly }\end{array}$ \\
\hline $\begin{array}{c}\text { Galindo- } \\
\text { Rodriguez et } \\
\text { al } \\
(2003)^{49}\end{array}$ & 11 & $\begin{array}{l}\text { Refractory nephrotic } \\
\text { syndrome and } \\
\text { proteinuria despite } \\
\text { immunosuppressive } \\
\text { therapy }\end{array}$ & $\begin{array}{c}\text { 800-1600 mg } \\
\text { daily }\end{array}$ & - & 6 months & $\begin{array}{l}\text { Proteinuria reduced } \\
\text { significantly }\end{array}$ \\
\hline $\begin{array}{l}\text { Renke et al } \\
(2010)^{50}\end{array}$ & 22 & $\begin{array}{l}\text { Non-diabetic patients } \\
\text { with proteinuria }\end{array}$ & $\begin{array}{c}1200 \mathrm{mg} \text { daily } \\
+ \text { ACEI or } \\
\text { ARB }\end{array}$ & $\begin{array}{l}\text { Placebo + } \\
\text { ACEI or } \\
\text { ARB }\end{array}$ & 8 weeks & Proteinuria reduced \\
\hline $\begin{array}{l}\text { Lin et al } \\
(2008)^{51}\end{array}$ & 85 & $\begin{array}{l}\text { Patients with CKD } \\
\text { and proteinuria }\end{array}$ & $\begin{array}{l}\text { 400-800 mg } \\
\text { daily }\end{array}$ & $\begin{array}{l}\text { Untreated } \\
\text { control } \\
\text { group }\end{array}$ & 12 months & $\begin{array}{l}\text { Proteinuria decreased, No } \\
\text { notable change in GFR }\end{array}$ \\
\hline $\begin{array}{l}\text { Perkins et al } \\
\quad(2009)^{52}\end{array}$ & 40 & Patients with CKD & $800 \mathrm{mg}$ daily & Placebo & 1 year & $\begin{array}{l}\text { Slower decrease in GFR, } \\
\text { Proteinuria was not } \\
\text { different between group }\end{array}$ \\
\hline
\end{tabular}


and lupus nephritis have also shown that PTF can attenuate proteinuria in these types of kidney diseases. Clinical trials demonstrating antiproteinuric effect of PTF in patients with nondiabetic renal diseases are summarized in Table 3.

In a prospective pilot study on 10 patients with biopsy-proved membranous nephropathy and persistent nephrotic syndrome despite maximum ACEI treatment, Ducloux et al. demonstrated that in nine patients received PTF treatment (1200 $\mathrm{mg}$ /day) for 6 months, remission of proteinuria was achieved. Importantly, these patients did not receive any immunosuppressive therapy (51). The antiproteinuric effect of PTF (400 mg twice daily, for 6 months) was also demonstrated in a small study in 17 non-diabetic patients with primary glomerular disease (34). Also, Galindo-Rodriguez et al. demonstrated that add-on PTF (800-1600 $\mathrm{mg} /$ day) for 6 months significantly reduced proteinuria in 11 patients with refractory nephrotic syndrome and proteinuria despite immunosuppressive therapy (52).

In a placebo-controlled, randomized study, the influence of PTF $(1200 \mathrm{mg} /$ day $)$ added to RAAS blockade on proteinuria, was evaluated in 22 nondiabetic patients with proteinuria in an eight-week run-in period. PTF therapy reduced proteinuria (by $26 \%$ ) in this population as compared to placebo (53).

A randomized controlled study evaluated the additional effect of PTF on proteinuria and GFR in 85 patients with CKD who were already receiving the ARB, losartan. PTF added to losartan therapy for 1 year decreased proteinuria in patients with CKD stages 3 to 5, but no notable change was seen in GFR (54). In contrast, different results have been seen in a placebo-controlled study by Perkins et al, in which the efficacy of PTF (400 mg twice daily) to slow the GFR decrease and attenuate proteinuria was evaluated in 40 patients with chronic kidney disease. According to the results, for PTF-treated participants, the mean estimated GFR decrease during treatment was slower compared with the year before study enrollment, but proteinuria was not different between the PTF and placebo groups at baseline, 6 months, or 1 year. The authors concluded that PTF may slow the estimated GFR decrease in high-risk patients and this may be independent of its antiproteinuric properties (55).

\section{CONCLUSION}

In summary, a total of 7 animal studies, 13 randomized controlled trials on diabetic kidney disease, and 6 studies on a variety of non-diabetic kidney diseases have been reviewed. The results from most of these studies consistently demonstrate that short-term use of PTF produce a significant reduction of proteinuria and microalbuminuria in patients with diabetic and also non-diabetic kidney diseases $(13,26,44,46,48,53)$. The reports of long-term studies $(42,43,45,47,49-52)$ also show that urinary protein excretion exhibits a considerable reduction in patients treated with PTF; however, since these results are mostly based on clinical trials of small size, whether the additive antiproteinuric effect of PTF is sustained over time, and whether the long-term use of PTF could be a pharmacological alternative for delaying or preventing the development of ESRD, are among the questions that remained to be appropriately answered in large-scale clinical trials.

Also, data on the antiproteinuric effect of PTF in a wide range of non-diabetic kidney diseases are scarce. Only a few randomized controlled trials directly addressing the effect of PTF on renal function and proteinuria in non-diabetic patients have been reported. Most of those studies were of small size or short duration, and many did not include a placebo arm. Membranous nephropathy (MN) was the subject of one of these studies. Despite a multitude of investigation over the last years, the treatment of membranous nephropathy remains both controversial and suboptimal. Recent progress in the molecular pathways of inflammation and immunologic regulation warrants further investigation on probable alternatives to the standard regimen of glucocorticoids and alkylating agents (56). Among the studied alternatives, PTF has shown its ability to reduce proteinuria in the solely study in patients with MN. In this pilot study described previously (51), monotherapy with PTF markedly reduced proteinuria in 10 patients with $\mathrm{MN}$ who were not receiving any other medication. This study did not include the placebo arm. Indeed, the PTF's benefit when administered in conjunction with standard treatment protocol in patients with most non-diabetic kidney diseases is not clear. Considering the prognostic impact of proteinuria reduction on long-term renal outcome in progressive kidney diseases namely $\mathrm{MN}$, we 
designed a six-months randomized placebocontrolled study evaluating the antiproteinuric effect of PTF addition to background nephroprotective therapy consisting of ACEI and/or $\mathrm{ARB}$, glucocorticoids and alkylating agents in patients in which MN was newly diagnosed based on histological studies. The study is now recruiting and the results will be released in 2014. This study may help to answer the question of whether PTF further improves renal outcome in $\mathrm{MN}$ patients already receiving standard therapy.

\section{Future Perspective}

Proteinuria is a well-recognized risk factor for cardiovascular and renal disease; hence, its early pharmacological treatment is a matter of clinical relevance. Little treatment is available to promote the reduction of proteinuria once that is established. In this regard, although ACE inhibitors have been cited as the first line of therapy, new data showing the beneficial effect of PTF on the reduction of microalbuminuria and overt proteinuria are rapidly increasing. Major studies focused on the use of PTF as an antiproteinuric agent reviewed here. Almost all studies showed that PTF administration to patients with proteinuric nephropathy was associated with a significant reduction of proteinuria after short- or long-term follow-up. However, the findings of presently described studies need to be confirmed in adequately powered, high-quality controlled trials before recommending the use of PTF in patients with progressive CKD. During the next years, the results of ongoing trials will ultimately determine whether PTF can really benefit clinical outcomes of this devastating disease.

\section{ACKNOWLEDGMENT}

This review is the outcome of an in-house nonfinancially supported study and authors declare no conflict of interest.

\section{REFERENCES}

1. Coresh J, Selvin E, Stevens LA et al.: Prevalence of chronic kidney disease in the United States. JAMA 298(17), 2038-2047 (2007).

2. Turgut F, Bolton WK: Potential new therapeutic agents for diabetic kidney disease. Am J Kidney Dis 55(5), 928-940 (2010).
3. van Dijk PC, Jager KJ, de Charro F et al:: Renal replacement therapy in Europe: the results of a collaborative effort by the ERA-EDTA registry and six national or regional registries. Nephrol Dial Transplant 16(6), 1120-1129 (2001).

4. Vilayur E, Harris DC: Emerging therapies for chronic kidney disease: what is their role? Nat Rev Nephrol 5(7), 375-383 (2009).

5. Ravera M, Re M, Weiss U, Deferrari L, Deferrari G: Emerging therapeutic strategies in diabetic nephropathy. J Nephrol 20 Suppl 12, S23-32 (2007).

6. Zandi-Nejad K, Eddy AA, Glassock RJ, Brenner BM: Why is proteinuria an ominous biomarker of progressive kidney disease? Kidney Int Suppl (92), S76-89 (2004).

7. McCormick BB, Sydor A, Akbari A, Fergusson D, Doucette S, Knoll G: The effect of pentoxifylline on proteinuria in diabetic kidney disease: a metaanalysis. Am J Kidney Dis 52(3), 454-463 (2008).

8. Perkins BA, Ficociello LH, Silva KH, Finkelstein DM, Warram JH, Krolewski AS: Regression of microalbuminuria in type 1 diabetes. $N$ Engl J Med 348(23), 2285-2293 (2003).

9. Rodriguez-Moran M, Guerrero-Romero F: Efficacy of pentoxifylline in the management of microalbuminuria in patients with diabetes. Curr Diabetes Rev 4(1), 55-62 (2008).

10. Hebert LA, Wilmer WA, Falkenhain ME, LadsonWofford SE, Nahman NS, Jr., Rovin BH: Renoprotection: one or many therapies? Kidney Int 59(4), 1211-1226 (2001).

11. Mogensen CE, Neldam S, Tikkanen I et al.: Randomised controlled trial of dual blockade of renin-angiotensin system in patients with hypertension, microalbuminuria, and non-insulin dependent diabetes: the candesartan and lisinopril microalbuminuria (CALM) study. BMJ 321(7274), 1440-1444 (2000).

12. Zoja C, Corna D, Camozzi D et al.: How to fully protect the kidney in a severe model of progressive nephropathy: a multidrug approach. $J$ Am Soc Nephrol 13(12), 2898-2908 (2002).

13. Navarro JF, Mora C, Muros M, Garcia J: Additive antiproteinuric effect of pentoxifylline in patients with type 2 diabetes under angiotensin II receptor blockade: a short-term, randomized, controlled trial. J Am Soc Nephrol 16(7), 2119-2126 (2005).

14. Ehrly AM: Improvement of the flow properties of blood: a new therapeutical approach in occlusive arterial disease. Angiology 27(3), 188-196 (1976).

15. De Sanctis MT, Cesarone MR, Belcaro G et al.: Treatment of intermittent claudication with pentoxifylline: a 12-month, randomized trial-walking distance and microcirculation. Angiology 53 Suppl 1, S7-12 (2002). 
16. Lin SL, Chen YM, Chien CT, Chiang WC, Tsai CC, Tsai TJ: Pentoxifylline attenuated the renal disease progression in rats with remnant kidney. $J$ Am Soc Nephrol 13(12), 2916-2929 (2002).

17. Chen YM, Ng YY, Lin SL, Chiang WC, Lan HY, Tsai TJ: Pentoxifylline suppresses renal tumour necrosis factor-alpha and ameliorates experimental crescentic glomerulonephritis in rats. Nephrol Dial Transplant 19(5), 1106-1115 (2004).

18. Radfar M, Larijani B, Hadjibabaie M, Rajabipour B, Mojtahedi A, Abdollahi M: Effects of pentoxifylline on oxidative stress and levels of EGF and NO in blood of diabetic type-2 patients; a randomized, double-blind placebo-controlled clinical trial. Biomed Pharmacother 59(6), 302-306 (2005).

19. Ranjbar A, Ghahremani MH, Sharifzadeh M et al.: Protection by pentoxifylline of malathion-induced toxic stress and mitochondrial damage in rat brain. Hum Exp Toxicol 29(10), 851-864 (2010).

20. Amirkabirian N, Teimouri F, Esmaily $\mathrm{H}$, Mohammadirad A, Aliahmadi A, Abdollahi M: Protection by pentoxifylline of diazinon-induced toxic stress in rat liver and muscle. Toxicol Mech Methods 17(4), 215-221 (2007).

21. Tsai TJ, Lin RH, Chang CC et al: Vasodilator agents modulate rat glomerular mesangial cell growth and collagen synthesis. Nephron 70(1), 9199 (1995).

22. Blagosklonnaia Ia V, Mamedov R, Kozlov VV, Emanuel VL, Kudriashova MI: [Effect of trental on indices kidney function in diabetes mellitus]. Probl Endokrinol (Mosk) 28(3), 3-8 (1982).

23. Ward A, Clissold SP: Pentoxifylline. A review of its pharmacodynamic and pharmacokinetic properties, and its therapeutic efficacy. Drugs 34(1), 50-97 (1987).

24. Sinzinger H: Pentoxifylline enhances formation of prostacyclin from rat vascular and renal tissue. Prostaglandins Leukot Med 12(2), 217-226 (1983).

25. Gorson DM: Reduction of macroalbuminuria with pentoxifylline in diabetic nephropathy. Report of three cases. Diabetes Care 21(12), 2190-2191 (1998).

26. Guerrero-Romero F, Rodriguez-Moran M, Paniagua-Sierra JR, Garcia-Bulnes G, SalasRamirez M, Amato D: Pentoxifylline reduces proteinuria in insulin-dependent and non insulindependent diabetic patients. Clin Nephrol 43(2), 116-121 (1995).

27. Navarro JF, Mora C: Antiproteinuric effect of pentoxifylline in patients with diabetic nephropathy. Diabetes Care 22(6), 1006-1008 (1999).

28. Wilmer WA, Rovin BH, Hebert CJ, Rao SV, Kumor $\mathrm{K}$, Hebert LA: Management of glomerular proteinuria: a commentary. $J$ Am Soc Nephrol 14(12), 3217-3232 (2003).
29. Usta Y, Ismailoglu UB, Bakkaloglu A et al.: Effects of pentoxifylline in adriamycin-induced renal disease in rats. Pediatr Nephrol 19(8), 840-843 (2004).

30. Chen YM, Chien CT, Hu-Tsai MI et al.: Pentoxifylline attenuates experimental mesangial proliferative glomerulonephritis. Kidney Int 56(3), 932-943 (1999).

31. Han KH, Han SY, Kim HS, Kang YS, Cha DR: Prolonged administration enhances the renoprotective effect of pentoxifylline via antiinflammatory activity in streptozotocin-induced diabetic nephropathy. Inflammation 33(3), 137-143 (2010).

32. Lin SL, Chiang WC, Chen YM, Lai CF, Tsai TJ, Hsieh BS: The renoprotective potential of pentoxifylline in chronic kidney disease. $J$ Chin Med Assoc 68(3), 99-105 (2005).

33. Lin SL, Chen YM, Chiang WC, Tsai TJ, Chen WY: Pentoxifylline: a potential therapy for chronic kidney disease. Nephrology (Carlton) 9(4), 198-204 (2004).

34. Chen YM, Lin SL, Chiang WC, Wu KD, Tsai TJ: Pentoxifylline ameliorates proteinuria through suppression of renal monocyte chemoattractant protein-1 in patients with proteinuric primary glomerular diseases. Kidney Int 69(8), 1410-1415 (2006).

35. Khoshakhlagh P, Bahrololoumi-Shapourabadi M, Mohammadirad A, Ashtaral-Nakhai L, Minaie B, Abdollahi M: Beneficial effect of phosphodiesterase-5 inhibitor in experimental inflammatory bowel disease; molecular evidence for involvement of oxidative stress. Toxicol Mech Methods 17(5), 281-288 (2007).

36. Dalla Vestra M, Mussap M, Gallina P et al.: Acutephase markers of inflammation and glomerular structure in patients with type 2 diabetes. $J \mathrm{Am} \mathrm{Soc}$ Nephrol 16 Suppl 1, S78-82 (2005).

37. McCarthy ET, Sharma R, Sharma M et al:: TNFalpha increases albumin permeability of isolated rat glomeruli through the generation of superoxide. $J$ Am Soc Nephrol 9(3), 433-438 (1998).

38. Segal R, Dayan M, Zinger H, Mozes E: Suppression of experimental systemic lupus erythematosus (SLE) in mice via TNF inhibition by an anti-TNFalpha monoclonal antibody and by pentoxiphylline. Lupus 10(1), 23-31 (2001).

39. Navarro JF, Milena FJ, Mora C, Leon C, Garcia J: Renal pro-inflammatory cytokine gene expression in diabetic nephropathy: effect of angiotensinconverting enzyme inhibition and pentoxifylline administration. Am J Nephrol 26(6), 562-570 (2006). 
40. Rossing P: Diabetic nephropathy: worldwide epidemic and effects of current treatment on natural history. Curr Diab Rep 6(6), 479-483 (2006).

41. Solerte SB, Fioravanti M, Bozzetti A et al.: Pentoxifylline, albumin excretion rate and proteinuria in type I and type II diabetic patients with microproteinuria. Results of a short-term randomized study [Abstract]. Acta Diabetol Lat 23(2), 171-177 (1986).

42. Solerte SB, Fioravanti M, Patti AL et al.: Pentoxifylline, total urinary protein excretion rate and arterial blood pressure in long-term insulindependent diabetic patients with overt nephropathy [Abstract]. Acta Diabetol Lat 24(3), 229-239 (1987).

43. Navarro JF, Mora C, Rivero A et al.: Urinary protein excretion and serum tumor necrosis factor in diabetic patients with advanced renal failure: effects of pentoxifylline administration. Am J Kidney Dis 33(3), 458-463 (1999).

44. Navarro JF, Mora C, Muros M, Maca M, Garca J: Effects of pentoxifylline administration on urinary $\mathrm{N}$-acetyl-beta-glucosaminidase excretion in type 2 diabetic patients: a short-term, prospective, randomized study. Am J Kidney Dis 42(2), 264-270 (2003).

45. Harmankaya O, Seber S, Yilmaz M: Combination of pentoxifylline with angiotensin converting enzyme inhibitors produces an additional reduction in microalbuminuria in hypertensive type 2 diabetic patients. Ren Fail 25(3), 465-470 (2003).

46. Aminorroaya A, Janghorbani $M$, Rezvanian $H$, Aminian T, Gharavi M, Amini M: Comparison of the effect of pentoxifylline and captopril on proteinuria in patients with type 2 diabetes mellitus. Nephron Clin Pract 99(3), c73-77 (2005).

47. Rodriguez-Moran M, Guerrero-Romero F: Pentoxifylline is as effective as captopril in the reduction of microalbuminuria in non-hypertensive type 2 diabetic patients--a randomized, equivalent trial. Clin Nephrol 64(2), 91-97 (2005).

48. Rodriguez-Moran M, Gonzalez-Gonzalez G, Bermudez-Barba MV et al.: Effects of pentoxifylline on the urinary protein excretion profile of type 2 diabetic patients with microproteinuria: a double-blind, placebo-controlled randomized trial. Clin Nephrol 66(1), 3-10 (2006).

49. Diskin CJ, Stokes TJ, Dansby LM, Radcliff L, Carter TB: Will the addition of pentoxifylline reduce proteinuria in patients with diabetic glomerulosclerosis refractory to maximal doses of both an angiotensin-converting enzyme inhibitor and an angiotensin receptor blocker? J Nephrol 20(4), 410-416 (2007).

50. Roozbeh J, Banihashemi MA, Ghezlou M et al:: Captopril and combination therapy of captopril and pentoxifylline in reducing proteinuria in diabetic nephropathy. Ren Fail 32(2), 172-178 (2010).

51. Ducloux D, Bresson-Vautrin C, Chalopin J: Use of pentoxifylline in membranous nephropathy. Lancet 357(9269), 1672-1673 (2001).

52. Galindo-Rodriguez G, Bustamante R, EsquivelNava G et al.: Pentoxifylline in the treatment of refractory nephrotic syndrome secondary to lupus nephritis. J Rheumatol 30(11), 2382-2384 (2003).

53. Renke M, Tylicki L, Rutkowski $\mathrm{P}$ et al.: Effect of pentoxifylline on proteinuria, markers of tubular injury and oxidative stress in non-diabetic patients with chronic kidney disease - placebo controlled, randomized, cross-over study. Acta Biochim Pol 57(1), 119-123 (2010).

54. Lin SL, Chen YM, Chiang WC, Wu KD, Tsai TJ: Effect of pentoxifylline in addition to losartan on proteinuria and GFR in CKD: a 12-month randomized trial. Am J Kidney Dis 52(3), 464-474 (2008).

55. Perkins RM, Aboudara MC, Uy AL, Olson SW, Cushner HM, Yuan CM: Effect of pentoxifylline on GFR decline in CKD: a pilot, double-blind, randomized, placebo-controlled trial. Am J Kidney Dis 53(4), 606-616 (2009).

56. Kshirsagar AV, Nachman PH, Falk RJ: Alternative therapies and future intervention for treatment of membranous nephropathy. Semin Nephrol 23(4), 362-372 (2003). 